\title{
Allocation of Funds from Public Offerings of Shares (IPO's) in Brazil and Stock Returns
}

\author{
George André Willrich Sales ${ }^{1}$, Rodolfo Leandro de Faria Olivo ${ }^{2}$, Rodolfo Vieira Nunes ${ }^{3} \&$ Fabiana Lopes da Silva ${ }^{1}$ \\ ${ }^{1}$ School of Business, Fundação Instituto de Pesquisas Contábeis, Atuariais e Financeiras (FIPECAFI), São Paulo, Brazil \\ ${ }^{2}$ School of Business, Fundação Instituto de Administração (FIA), São Paulo, Brazil \\ ${ }^{3}$ School of Management, Universidade de São Paulo (USP), São Paulo, Brazil \\ Correspondence: Rodolfo Vieira Nunes, School of Management, Universidade de São Paulo (USP), São Paulo, SP, 908 \\ Professor Luciano Gualberto Avenue, Butantã, ZIP: 05508-010, Brazil.
}

Received: January 18, 2021

doi:10.11114/ijsss.v9i2.5131
Accepted: February 19, $2021 \quad$ Available online: February 23, 2021

URL: https://doi.org/10.11114/ijsss.v9i2.5131

\begin{abstract}
This study analyzes the relationship between the allocation of funds raised in a public offering of shares and abnormal profitability on the first day of trading. The objective is to identify whether the allocation of resources can be considered for the decision-making of investors. To measure the data, multivariate analysis was used, and the data survey considered the information from the prospectuses of the public offers and the announcements for the closing of the offers, between January 2007 and December 2011. Two hypotheses were tested: one in relation to allocation of resources and another in relation to the group of investors participating in the offer. The results show that there is no relationship between the allocation of resources and the abnormal returns of companies. However, for investors who are part of the company's management, they were related to abnormal stock returns on the first day of trading.
\end{abstract}

Keywords: public offering, allocation, stocks, fund-raising

\section{Introduction}

\subsection{Introduce the Problem}

During the life cycle of a business, few financial events are as meaningful as the primary issue of stocks that, regardless of their type (common or preferred), may allow: the entry of new partners, the change of shareholding, the raising of transparency standards and the increase in corporate governance criteria.

The theme of this research involves the discussion about the information, presented in the prospectuses, where it is sought to assess whether the allocation of the funds raised are relevant to the formation of the stock price to the point of minimizing the variation in the closing value on the first trading day on the stock exchange. Investors who participated in the underwriting had, during the prior analysis of the public offering prospectus, access to several information, including the funds allocation information. However, in many cases, such prospectuses, which refer to hundreds of pages, do not make available more than one page to inform on the fund's allocation. That is why it is important to highlight the information relevance at the time of placement on the Stock Exchange.

According to data from Brazil Stock Exchange (B3) and the Brazilian Securities and Exchange Commission (CVM), Brazil experienced a significant increase in the number of companies that held IPOs in the period as from January 2007 to December 2011 - there were 154 public offerings, intended for primary market (underwriting) and / or secondary market (block trade). The financial volume reached $\mathrm{R} \$ 313.5$ billion for the period, which also includes the sum of the values of additional lots (up to $15 \%$ of the offer), and this amount is distributed in $\mathrm{R} \$ 250.9$ billion for underwriting and $\mathrm{R} \$ 62.5$ billion for block trade.

This study has as its core target the empirical analysis of the fund's allocation stated in the underwriting prospects of companies in the period January 2007 to December 2011, including the period of the global economic crisis that began in 2008 , due to the shares price variation on the first trading day. It was discarded from this study the analysis of block trade, as these are not intended to the entry of capital for the company and constitute a secondary market. The specific objectives are: 
I. Check whether there is a relationship between the use of information on the fund's allocation and the performance of shares on the first trading day; and

II. Check whether there is a preference relationship by type of investors due to the allocation of the funds raised in an initial public offering.

The present study may help companies and underwriters to assess whether the method used in formatting the allocation of funds raised in the public offering prospectus has a positive or negative effect on underpricing problems. As for market regulatory bodies, the mandatory disclosure of the fund's allocation stated in ICVM No. 400 and its subsequent updates, can be assessed with the work, that is, the perception of the need to be stricter or not as for the description of the item funds allocation in the public offering prospectuses. Also, as to the investors, using a variety of information to help find a fair price for a capital market asset is something that is appreciated; however, the information must be relevant, complete and assertive. Thus, the present work will help to assess whether the information on the funds' allocation is or should be priced in the shares offered or whether they bring only a speculative factor that in no way contributes to the final effort.

There are no reports of Brazilian studies specifically on the possibility that the information concerning the allocation of the funds raised will be able to help in the analysis of the issuance pricing, that is, at the time of book building until the effective placement of the stock on the stock exchange.

This article is organized into five sections. The first section deals with the introduction and context of the research. The next section deals with the theoretical foundation. The third section depicts the methodological procedures adopted and the analyzed sample. The fourth section reports the findings analysis and their discussions. Finally, in the last section, the final considerations are presented, as well as the limitations and suggestions for future research.

\subsection{Theoretical Background}

\subsubsection{Access to the Capital Market in Brazil}

Companies can access investors in the primary market in three ways: (i) through a public offering, in which they offer their shares for sale to the general public; (ii) through subscription rights, in which the new shares are sold to current shareholders; (iii) through private placement, in which the company sells its securities directly to an investor or group of qualified investors. The focus of this study is related to the first form (i). When a company holds a public offering through the opening of its capital to new partners, in public access markets (stock exchange and OTC) we are dealing with an IPO - initial public offering. In this process, the IPO can be of a primary (underwriting) or secondary (block trade) nature, which comes from shares already issued and not affecting the capital stock and, consequently, the company's cash. Such a public offering may be of a mixed nature.

ICVM No. 400 and its subsequent updates, regulate the offers of securities distribution in the Brazilian market and aims to ensure and protect the interests of investors and popular savings in general, providing that all investors have equal treatment in relation to the assets offered, through broad, transparent and appropriate disclosure of information about the company and what is being offered.

Based on these principles, the disclosure to be presented in the prospectus must contain mandatory information, such as: (i) summary containing the characteristics of the transaction; (ii) Identification of managers, consultants and auditors; (iii) Composition of Capital Stock; (iv) Securities distribution Agreement; (v) Liquidity guarantee and price stabilization Agreement; (vi) Agreement of supplementary lot placement option; (vii) Economic and financial feasibility study; (viii) Risk factors; (ix) financial situation and its analysis by management; (x) Financial statements of the last financial year and description of Property, Plant, and Equipment (PP\&E); (xi) Organizational structure; (xii) information on judicial and administrative contingencies; (xiii) Minutes of the Extraordinary General Meeting - EGM or meeting of the Board of Directors who authorized the issuance; (xiv) updated issuer's bylaws; (xv) Report of the rating agency.

For this study, we will address in particular the item Allocation of Funds. Below is the article dealing with ICVM No. 400 and its subsequent updates:

"Art. 30 Paragraph 1 The Prospectus must contain a specific section dealing with the allocation of funds according to the amount of securities to be distributed or the amount of funds to be raised, as well as the possible alternative source of funds, if distribution or partial funding is permitted".

The Annex II of ICVM No. 400 and its subsequent updates provide details on how the presentation of the Funds Allocation in the prospectus should be done. All aspects relating to Documents and Information Required for Registration are dealt with here. It follows below the legal requirement:

\section{"3.5 FUNDS ALLOCATION (only applicable to the distribution of securities issued by the offeror himself)}


3.5.1 Clear and objective presentation of the allocation of funds coming from the issue, as well as their impact on the issuer's equity situation and results;

3.5.1.1 If the funds are used, directly or indirectly, to acquire assets, with the exception of those acquired in the regular course of business, briefly describe these assets and their costs. If such assets are acquired from related parties, inform from whom they will be purchased and how the cost will be determined;

3.5.1.2 If the funds are used to acquire other businesses, provide a brief description of these businesses and the stage of the acquisitions. If purchased from related parties, inform from whom they will be purchased and how the cost will be determined;

3.5.1.3 If a significant part of the funds is used to write off debts, describe the interest rate and term of these debts and, for those incurred as from the previous year, present the allocation of those funds, pursuant to items 3.5.1.1 and 3.5.1.2; and

3.5.1.4 If only part of the funds is obtained through distribution, describe what other forms of funding are expected to achieve its target. And if there are several targets and only part of the funds is raised, describe which objectives will be a priority.

3.5.2 Other Sources of Funds - If any, describe other sources of funds which will have an allocation associated with that related to public distribution; and

\subsubsection{Alternative sources of funding, in case of partial distribution".}

\subsubsection{Reasons for Fundraising}

In the public offering prospectuses, it was found the following reasons of funds allocation for the issuance of new shares: (i) acquisition of competitors or the incorporation of new ventures (ii) modernization of products or investment in production; (iii) provision of credit or increasing payment terms to its customers; (iv) payment of previous debts and (v) use as working capital.

As a theoretical basis for this study, it is listed below the main theories that can explain the reasons for raising funds via IPO.

\subsubsection{Theory of Hierarchization of Funding Sources (Pecking Order Theory)}

Several approaches on capital structure were prepared from the seminal study of Modigliani and Miller (1958), highlighting the approach of Myers and Majluf (1984), which revealed the existence of an order of preference to finance companies - the Pecking Order Theory. These authors suggested that the informational asymmetry created an order for financing: first, the retained earnings; second, the private debt (loans and financing) and third, the issuance of public debt (debentures) and shares. This approach was tested by several authors, especially by Brealey et al. (2008), Corbett and Jenkinsin (1997), Brau and Fawcett (2006), among others. Brau and Fawcett (2006, p. 39) "researched with 336 CFOs the reasons that would lead the company to the IPO and compared the theory with practice, coming to a conclusion that there is an order of relevance, and duly adapted to the information in the public offering prospectuses".

\subsubsection{Signaling Theory}

The signaling theory aims to analyze the situations in which the opposing parties, in contractual negotiations, are interested in highlighting, or rather, signaling some characteristics, in order to minimize the problem of information asymmetry before closing the operation. This is on the assumption that the agent will be interested in revealing his private information by making it public if it brings greater benefits. Obviously, if there are costs to construct and disseminate the information and the benefits are sufficient to cover them, there will be no signaling.

From the perspective of the Signaling Theory, it would be possible to indicate whether the information quality about the funds raised allocation, presented in the public offer prospectuses by the companies, would influence investors' decision-making. However, in the public offer prospectuses of the companies which were the object of this study, as previously stated, present the minimum required by the rules, which make it difficult to compare the information quality.

\subsubsection{Market Timing Theory}

Other works address different motivations to make offerings and among them are the favorable market conditions, the largest exhibition in advertising, corporate restructuring, divestment, currency exchange, and finally the average capital structure of companies in the sector.

Market conditions present the idea that companies choose the best time to go public in order to raise funds. Companies postpone their offerings if they realize that their shares are undervalued, according to the market timing theory (Korajczyk et al., 1991). If in the period, the shares of companies in the same sector are overvalued, it is natural that 
good companies perform underwriting. Ritter (1991) treated this window of opportunities as a market-to-book, as the investor sees this movement as a growth in the sector, forcing the company to go in search of capital to finance itself.

\subsection{The Underpricing Problem}

Fundraising through underwriting can generate an initial discount for the company, called underpricing (positive return on shares on the first trading day at the stock exchange). Several authors have studied this phenomenon related to IPO's, mentioning the studies of Keloharju (1993), Ljundqvist and Boehmer (2001), Loughran and Ritter (2002) and Aggarwal, Hernandez and Leal (1993).

The adoption of mechanisms that produce more qualified information could reduce the problem of asymmetric information and hence the underpricing problem. Based on this idea, the researchers Saito and Maciel (2006) studied the adoption of ICVM 400 of 2003, from January 1999 to March 2006, in a sample of 27 IPOs. The result showed an underpricing of $-0.4 \%$ for the Pre-ICVM 400 period (with 11 samples) and $10.4 \%$ for the Post-ICVM 400 period (with 16 samples). Based on these results, the adoption of ICVM was not relevant.

\subsection{Theories Based on Information Asymmetry}

Theories of finance based on information asymmetry (or based on the Efficient Market Hypothesis - EMH) are the most used to explain the return on the first trading day. This situation arises from the fact that some parties have more information about the offering than others, and the encouragement for less informed investors entry would be related to the possibility of underpricing.

According to Fama (1976, p. 133) "An efficient capital market is one that is efficient in processing information". Thus, the price of a stock reflects all available information with direct implications for investors and companies. In short, we can understand that transparency of information must be the goal to be pursued by investors and regulators for the fair pricing of assets in the capital market. According Iudícibus and Lopes (2004, p. 70) "[...] The EMH - Efficient Market Hypothesis provided the Accounting the possibility of checking the relationship of accounting figures and economic variables."

\subsection{Theory of Fractals}

The EMH - Efficient Market Hypothesis, which considers a number of assumptions, is criticized for failing to clearly explain some market variations. In this case, these variations are called anomalies. Anomalies are considered by EMH Efficient Market Hypothesis, as a way of obtaining gains in the stock market, and to justify this thought, some researchers isolated some of these effects, such as: company size, cyclical period, Price / Profit index, Price / Book Value index, liquidity.

As the EMH - Efficient Market Hypothesis is heavily dependent on the assumption that investors make decisions based on rational thinking, the linear paradigm on the way investors operate has been questioned, especially after Kahneman's studies (2003). In short, the behavior rated by Kahneman (2003) departs from the rationality hypothesis, since the investor can act with overconfidence and, in this case, disregard relevant information, as long as this information does not fit the previously chosen scenario.

In the same line of thought, Peters (1991) has observed in his studies that investors do not react linearly in view of new information received, as many of this information are momentarily ignored, which can generate a delayed reaction. According to Peters (1994), the Fractal Markets Hypothesis is emphasized by the investor behavior impact in view of the liquidity and investment horizon and, thus, based on empirical observations, the Fractal Markets Hypothesis seeks to present models that justify the investors behavior and price moves in the markets.

\section{Method}

\subsection{Population and Sample}

For this research it was used companies that tendered shares in the period January 2007 to December 2011, with the primary source of information the CVM site for collection of public offer prospectuses shares. During this period 154 stock placements were performed using the public offering instrument, and 132 stock placements, from 105 different companies, were considered for this paper, as they carried out the placement in a primary or mixed manner.

Information on the final prices of the offers, as well as the total raised from the offer, were extracted from communicated to the market on closing the deals, available on the websites of B3 and CVM. In turn, the closing prices of the first trading day at the B3 session were obtained from the Economatica ${ }^{\circledR}$ database. The software used in this work were the R2, Stata ${ }^{\circledR}$ and Excel®.

\subsection{Theoretical and Operational Definitions of Variables}

\subsubsection{Dependent Variable: Abnormal Return on the First Trading Day}

As study dependent variable it will be used the abnormal return of primary and mixed issuances of shares on their first 
trading day on the B3 session, according to Ritter and Welch (2002), given by:

$A R_{i, i p o}=\left[\left(\frac{p_{i, F, t}}{p_{i, o}}\right)-1\right]-R_{i b o v, t}$ Being:

$\mathrm{AR}_{\mathrm{i}, \text { po }}=$ Abnormal return of asset $i$ on the IPO

$p_{i, F, t}=$ observed price of the asset $i$ at the end $F$ of the trading day $t$

$p_{i, O}=$ observed price of the asset $i$ at the closing of the prospectus $O$

$\mathrm{R}_{\mathrm{ibov}, \mathrm{t}}=$ Return of Ibovespa $i b o v$ for the first trading day $t$

2.2.2 Independent Variables

\subsubsection{Funds allocation}

The variable Funds Allocation used in this paper concerns mandatory information in the public offering prospectuses, which invariably are presented as percentages in relation to the value of primary fundraising.

According to studies related to the capital structure, the market tends to price companies' shares on account of their liability structure. The signaling theory could also help to explain whether the allocation presented as satisfactory to the market would imply an abnormal low or null return (Morris, 1987; Varian, 2006; Dalmácio, 2009). However, other studies, such as the fractal theory, point out that such a relationship between pricing and information given to the market is not confirmed in the expected way, especially in times of significant fluctuations, but rather depending on the investors' behavior combined with the investment horizon (Peters, 1991; Peters, 1994; Kahneman, 2003). Therefore, for each allocation indication, it is expected that investors have distinct behaviors, as outlined below:

- the settlement of the Liabilities (Reduction of Liabilities) should not have a positive effect on investors, as such information suggests that the company is facing difficulties in obtaining financing through other means. However, if the justification is the liability restructuring, it is possible that the investors' behavior is different;

- the funding for Cash and Cash Equivalents (Working Capital) should not have a positive effect on investors, as such information suggests that there is not an adequate compatibility between revenues and short-term debts;

- credit supply (Customers) may have a positive effect on investors, as such information suggests that if the company is the financing link in its production chain, despite the existence of instruments for assigning credit rights capable of financing the company and, consequently, their customers. However, if the company is a financial institution, such information suggests difficulty in raising funds from investors through fixed income instruments, being interpreted negatively by the market;

- Modernization / Production (Modernization and Business Recovery; Investment in Infrastructure, Coverage of Operations Initial Costs, Project Implementation), can have positive effects with investors, if the funding is for new projects implementation and / or coverage of initial implementation costs, such information suggests that the company may increase its profit in the future. However, if the understanding is that the company should have retained part of its profits, over previous periods, to amortize the effects of depreciation and modernization, the result could be negative;

- the Acquisitions / Mergers (Restructuring, Fixed Assets Investment, Investment or Acquisition of Equity Holdings) should have a positive effect, as it suggests a structural increase and economies of scale which may improve earnings per share.

Table 1 below shows the encoding used in this paper to identify the different types of funds allocation.

Table 1. Classification of the funds' allocation

\begin{tabular}{ll}
\hline Code & Funds Allocation \\
\hline GIR & Percentage allocated to Cash or Cash Equivalents (Working Capital - WC) \\
PAS & Settlement of Liabilities (Liability Reduction) \\
FIN & Provision of Credit to Customers (Financing) \\
PRD & $\begin{array}{l}\text { Modernization / Production (Modernization and Business Recovery; Investment in Infrastructure, } \\
\text { Coverage of Operations Initial Costs, Project Implementation) }\end{array}$ \\
AQU & Acquisitions / Mergers (Restructuring, Fixed Assets Investment, Investment or Acquisition of \\
\hline
\end{tabular}

Source: Elaborated by the authors (2020). 


\subsubsection{Members of the Offer}

The variable Members of the Offer are types of investors who purchased the shares together with the absolute values of the final number of shares acquired, including the supplementary lots, which are presented in the closing announcement. According to the studies pointed out in the theories treated earlier, the volume ratio acquired by participant type, who has different investment horizons, may suggest a relationship that explains the abnormal return of a particular stock.

The theory of fractals could point to the existence of this relationship between pricing and information given to the market according to the type of investor, combined with its investment horizon (Peters, 1991; Peters, 1994; Kahneman, 2003). Therefore, for each type of member, different behaviors are expected, as shown below:

- Individuals (common and qualified investors) and Investment Clubs: the participation in the offer of this type of investor should not have an effect in relation to the abnormal return, since the knowledge about the companies' fundraising is only that made available by the offer placement agents;

- Investment Funds, Private Pension Funds and Insurance Companies: these are specialists who perform detailed analysis of the offers, including participating in Road Shows to determine the amount of their participation, which tends to be more assertive;

- Foreign Investors: offering companies can place shares through American Depositary Receipt (ADRs), to reach the North American market, involving the participation of specialized agents who carry out detailed analysis of offers, including participating in Road Shows to determine the amount of their participation, which tends to be more assertive;

- Corporate Brokers Participant of the Distribution Consortium: Participating in the Distribution Consortium: these are the Offering Coordinators, the Contracted Coordinators and the Consortium Institutions, when collective referred to, the mode of their participation in the offering is described in the prospectus of each offer. It is expected that their participation is related to the abnormal return;

- Financial Institutions Related to the Company and / or to the Participants in the Distribution Consortium: are the parties related to the issuer or distributors. It is expected that their participation is related to the abnormal return;

- Other Financial Institutions: these are institutions that are not connected to the distribution offer, as they are specialized agents who carry out detailed analysis of offers, including participating in Road Shows to determine the amount of their participation, they are expected to have a more assertive participation;

- Other Legal Entities Related to the Company and / or to the Participants in the Distribution Consortium: these are institutions that somehow have connections with the company or with the distributors. It is expected that their participation is related to the abnormal return;

- Other Legal Entities: they also follow the same line as individual investors and should not have an effect in relation to the offer, since the knowledge about the company's fundraising, too, is only that offered by the offer placement agents;

- Partners, Managers, Employees, Representatives and other persons connected to the Company and / or to the Participants in the Distribution Consortium: the manner of their participation in the offering is described in the prospectus of each offer. It is expected that their participation is related to the abnormal return;

- Other Investors: are investors who do not fit into any of the other types and also follow the same line as individual investors and should not have an effect in relation to the offer, since the knowledge about the company's fundraising, too, is only those offered by the offering agents; and

- Shares Repurchased in the Scope of Stabilization Activities: The purchase of shares of its own issue can be defined as a company's strategy for reducing agency costs, to signal that its shares are undervalued by the market. When the stock is placed on the market, there may be a period of liquidity instability, since some companies assume that there may be an abnormal return, therefore, they adopt the practice of Repurchase for Stabilization. The way in which this Stabilization Repurchase practice will be operationalized, should be described in the prospectus.

Table 2 below shows the encoding used in this work to identify the different types of investors participating in the offer. 
Table 2. Classification of investors participating in the offer

\begin{tabular}{ll}
\hline Code & Investors \\
\hline PF & Individuals \\
CI & Investment Clubs \\
FI & Investment Funds \\
EPP & Private Pension Funds \\
CS & Insurance Companies \\
IE & Foreign Investors \\
IIP & Corporate Brokers Participating in the Distribution Consortium \\
IFL & Financial Institutions Related to the Company and / or to the Distribution Consortium \\
DIF & Participants \\
DPJL & Other Financial Institutions \\
DPJ & Other Legal Entities Related to the Company and / or to the Distribution Consortium \\
ADM & Participants \\
OI & Other Legal Entities \\
REC & Partners, Managers, Employees, Representatives and other persons related to the Company \\
\hline
\end{tabular}

Source: Elaborated by the authors (2020).

\subsubsection{Control Variables}

Control variables presented in the finance literature are used as possible determinants of performance, and these variables were available both in the public offering prospectuses as well as for the participating investors. Financial data (balance sheet) were collected from the public offering prospectuses and reflect the closing of the balance sheet for the last fiscal year before the date of the offering.

In Table 3 we have a summary of some information on the indicators used as control variables in this research.

Table 3. Financial indicators

\begin{tabular}{|c|c|c|c|}
\hline Indicators & Formula & Definition & Autors \\
\hline Economic Sector of Activity & ESA & $\begin{array}{l}\text { The variable market conditions is } \\
\text { the main factor for a public } \\
\text { offering. Favorable market } \\
\text { conditions and increased exposure } \\
\text { to advertising may be the IPO } \\
\text { factor }\end{array}$ & Ritter and Welch (2002) \\
\hline Total Assets & TA & $\begin{array}{l}\text { The total assets of the company } \\
\text { can be translated as its size and, } \\
\text { therefore, could explain the reason } \\
\text { for the investors' entry in a public } \\
\text { offering }\end{array}$ & Ritter and Welch (2002) \\
\hline Margin EBITDA & $\begin{array}{c}\text { ME = EBITDA / NET OPERATING } \\
\text { REVENUE }\end{array}$ & $\begin{array}{l}\text { Is a measure of financial } \\
\text { performance that works as a tool to } \\
\text { assess the operational efficacity } \\
\text { and justify the administrative } \\
\text { decisions adopted by companies. }\end{array}$ & Ritter and Welch (2002) \\
\hline Leverage & LEV = NET DEBT / NET WORTH & $\begin{array}{c}\text { This indicator the relationship } \\
\text { between the amount of money that } \\
\text { a company or organization owes } \\
\text { and the value of the company or } \\
\text { organization }\end{array}$ & $\begin{array}{l}\text { Myers and Majluf } \\
\text { (1984); Kayo (2002) }\end{array}$ \\
\hline Return on Assets & $\begin{array}{c}\text { ROA }=\text { OPERATING PROFIT } / \\
\text { TOTAL ASSETS }\end{array}$ & $\begin{array}{l}\text { Indicator that shows how } \\
\text { profitable the company is in } \\
\text { relation to its total assets, and } \\
\text { provides a view of how efficient } \\
\text { the company's management is in } \\
\text { using its assets to generate } \\
\text { earnings. }\end{array}$ & $\begin{array}{l}\text { McGuire, Sundgren and } \\
\text { Schneeweis (1988); } \\
\text { Lopes and Galdi (2007) }\end{array}$ \\
\hline
\end{tabular}

Source: Elaborated by the authors from Myers and Majluf (1984), McGuire, Sundgren and Schneeweis (1988), Ritter and Welch (2002), Kayo (2002) and Lopes and Galdi (2007). 


\subsection{Econometric Model}

For this study, based on the theoretical basis and previous studies, the following hypotheses are proposed, presented in their null form:

- $\mathrm{H}_{0,1}$ (null hypothesis 1): The existence of information on the funds allocation in the prospectus of a public offering, according to their allocation, affects the shares prices listed on the primary market on the first trading day.

- $\mathrm{H}_{0,2}$ (null hypothesis 2): There are intrinsic relationships between the types of investors with the variation of the stock price offered in the primary market on the dates of their placements.

$$
\begin{array}{r}
+\beta_{8, i} M E+\beta_{9, i} D L P L+\beta_{10, i} R O A+\varepsilon_{i} \quad, i=1, \ldots, N \\
=\alpha_{i}+\beta_{1, i} G I R+\beta_{2, i} P A S+\beta_{3, i} F I N+\beta_{4, i} P R D+\beta_{5, i} A Q U+\beta_{6, i} S T R+\beta_{7, i} A T V
\end{array}
$$

The general regression model used to answer $\mathrm{H}_{0,1}$ is as follows, according to the defined variables for the study:

$$
+\beta_{15, i} A T V+\beta_{16, i} M E+\beta_{17, i} D L P L+\beta_{18, i} R O A+\varepsilon_{i} \quad, i=1, \ldots, N \quad \text { (2) } \beta_{8, i} I F L+\beta_{9, i} D I F+
$$

$\beta_{10, i} D P J L+\beta_{11, i} D P J+\beta_{12, i} A D M+\beta_{13, i} O I+\beta_{14, i} R E C A R_{i}=\alpha_{i}+\beta_{1, i} P F+\beta_{2, i} C I+\beta_{3, i} F I+\beta_{4, i} E P P+\beta_{5, i} C S+$ $\beta_{6, i} I E+\beta_{7, i} I I P+$ In turn, the general regression model used to answer $\mathrm{H}_{0,2}$ is as follows, according to the variables defined for the study.

For both equations: the $\alpha_{\mathrm{i}}$ represents the intercept and the $\varepsilon_{\mathrm{i}}$ is the regression error term.

The STR variable is the classification of companies in sectors of the economy, such as: Construction / Transportation; Cyclic Consumption; Non-Cyclical Consumption; Financial and Other; Basic Materials; Oil, Gas and Biofuels; Information Technology; Telecomunications and Utilities.

\section{Results and Discussion}

Initially, the descriptive analysis of the variables was performed, and a significant positive asymmetry was observed in the dependent variable, abnormal return, and a criterion was adopted to remove outliers from the sample, in order to minimize possible problems related to inference in the results. As for the other variables, no significant distortions were observed for this work. Thus, according to the adopted criterion, the following companies in the studied sample were eliminated:

Table 4. Outliers removed from the sample

\begin{tabular}{ccc}
\hline Companies discarded from the sample & Date of the offerings & Abnormal Return \\
\hline Amil & October/2007 & $15,02 \%$ \\
Anhanguera Educ. & March/2007 & $21,13 \%$ \\
Brasil Insurance & October $/ 2010$ & $26,15 \%$ \\
GVT AS & February/2007 & $27,45 \%$ \\
Le Lis Blanc & April/08 & $-17,18 \%$ \\
MRV Engenharia & July/2007 & $18,20 \%$ \\
Redecard & July/2007 & $24,02 \%$ \\
Rodobens & January/2007 & $15,31 \%$ \\
São Martinho & February/2007 & $19,09 \%$ \\
\hline
\end{tabular}

Source: Prepared by the authors (2020).

Correlation tests were carried out regarding the independent variables and the control variables. The results suggest that there is no evidence of multicollinearity between the variables, making them suitable for testing the hypotheses of this study. The results of descriptive analysis and correlation tests are omitted here for space reasons.

Then, the model $\mathrm{H}_{0,1}$ was tested in two different specifications (with and without the control variables), in both cases the model is the pooling one and does not take into account the effect of time on the studied relationship. The first test considered the $\mathrm{H}_{0,1}$ model without the control variables, while the second test considered the full model, with the control variables - presented in Table 5. 
Table 5. Study model H0,1 with control variables

\begin{tabular}{|c|c|c|c|c|}
\hline & Coefficient & $\begin{array}{l}\text { Standard } \\
\text { deviation }\end{array}$ & $\mathrm{t}$ value & $\operatorname{Pr}(>|t|)$ \\
\hline Intercept & -0.0248140 & 0.0481679 & -0.515 & 0.607538 \\
\hline GIR & 0.0532296 & 0.0373757 & 1.424 & 0.157389 \\
\hline PAS & -0.0253463 & 0.0273079 & -0.928 & 0.355471 \\
\hline FIN & 0.0122387 & 0.0259499 & 0.472 & 0.638182 \\
\hline PRD & -0.0130447 & 0.0163576 & -0.797 & 0.426993 \\
\hline AQU & -0.0260513 & 0.0216558 & -1.203 & 0.231719 \\
\hline STR[T.Construction / Transportation] & -0.0061845 & 0.0314346 & -0.197 & 0.844414 \\
\hline STR[T. Cyclic Consumption] & 0.0276919 & 0.0326183 & 0.849 & 0.397848 \\
\hline STR[T.Non-Cyclical Consumption] & 0.0203184 & 0.0324819 & 0.626 & 0.532993 \\
\hline STR[T.Financial and Other] & 0.0042315 & 0.0330525 & 0.128 & 0.898378 \\
\hline STR[T.Basic Materials] & -0.0136851 & 0.0356978 & -0.383 & 0.702235 \\
\hline STR[T.Oil, Gas and Biofuels] & 0.0002766 & 0.0380501 & 0.007 & 0.994214 \\
\hline STR[T.Information Technology] & 0.1214584 & 0.0602915 & 2.015 & 0.046536 \\
\hline STR[T.Telecomunications] & -0.0320508 & 0.0628450 & -0.510 & 0.611133 \\
\hline STR[T.Utilities] & 0.0112008 & 0.0495395 & 0.226 & 0.821569 \\
\hline ATV & 0.0049645 & 0.0063827 & 0.778 & 0.438450 \\
\hline ME & 0.0084602 & 0.0053725 & 1.575 & 0.118357 \\
\hline DLPL & -0.0059695 & 0.0017302 & -3.450 & 0.000811 \\
\hline ROA & 0.1040491 & 0.0510655 & 2.038 & 0.044133 \\
\hline $\mathrm{N}=$ & 104 & $R^{2}=$ & 0.2246 & \\
\hline F-statistic $=$ & 1.674 & $\mathrm{p}$-value $=$ & 0.05592 & \\
\hline Min & $1 \mathrm{Q}$ & Median & $3 \mathrm{Q}$ & Max \\
\hline-0.135860 & -0.024603 & -0.000389 & 0.024550 & 0.142997 \\
\hline$*$ - Significant in $10 \%(0,10)$ & \multicolumn{2}{|c|}{$* *$ - Significant in $5 \%(0,05)$} & \multicolumn{2}{|c|}{$* * *$-Significant in $1 \%(0,01)$} \\
\hline
\end{tabular}

Source: Prepared by the authors (2020).

In both models, it is observed that all independent variables do not have statistical significance in the model, suggesting no relationship between the Abnormal Return (RA) on the first trading day and the funds allocation presented in the public offering prospectuses. Thus, such evidence suggests that the funds allocation described in the public offering prospectuses do not take effect on investors and do not cause the Abnormal Return (RA) of shares on the first trading day.

The STR control variable (Information Technology) had 5\% statistical significance. It is possible that the sectorial risk is related to the abnormal return, however the sample had only one company in this sector, which does not allow such an inference.

The control variables ATV (Total Company Assets) and ME (Ebitda Margin) did not take effect on the model, and a relationship is expected for both variables. As for the control variable DLPL, statistical significance was observed in the model of $1 \%$, that is, the net debt ratio on equity seems to be the one that best explains the abnormal return, within the model. Thus, we can conclude that the indicator is possibly used to assess the price of a share, especially in the initial moment of stock trading, where the price formation by the market is not yet clear.

This observation is in line with previous studies such as Myers and Majluf (1984) that showed the existence of an order of preference for financing a company and also the study by Kayo (2002) that presented a relationship between third party capital and equity with a company's financial risk, where the higher the financing with capital of third parties the higher the leverage. 
Finally, ROA is presented explaining the abnormal returns to the level of significance of 5\%. Previous studies such as those by Mcguire et al. (1988), Lopes and Galdi (2007) and Lopes and Martins (2010) the latter about the shares repurchase through fundamental analysis, also suggested the ROA as a liquidity indicator to segregate winner companies from the loser ones.

In order to improve the $\mathrm{F}$ statistical result, the $\mathrm{H}_{0,1}$ model was also tested considering the independent variables on a logarithmic basis along with the heteroscedasticity tests. Such a feat made the model more robust, however the results analysis remains unchanged and, for this reason, they are not listed in this work.

The $\mathrm{H}_{0,2}$ model was also tested in two different specifications. In both cases, the model is the pooling one and does not regard the effect of time on the studied relationship. The first test considered the $\mathrm{H}_{0,2}$ model without the control variables, while the second test considered the full model, with the control variables.

According to the results reported in Table 6 (without the control variables), it is observed that the independent variables PF, CI, FI, EPP, IE, IIP, IFL, DIF, DPJL, DPJ, and OI have no statistical significance in the model, suggesting no relationship between the Abnormal Return (AR) and the entry of these investors in the public offerings. However, the independent variables CS with negative return at the significance level of $10 \%$, ADM with negative return at the significance level of 5\% and REC with positive return at the significance level of $1 \%$ showed statistical relevance.

Table 6. Study model H0,2 without control variables

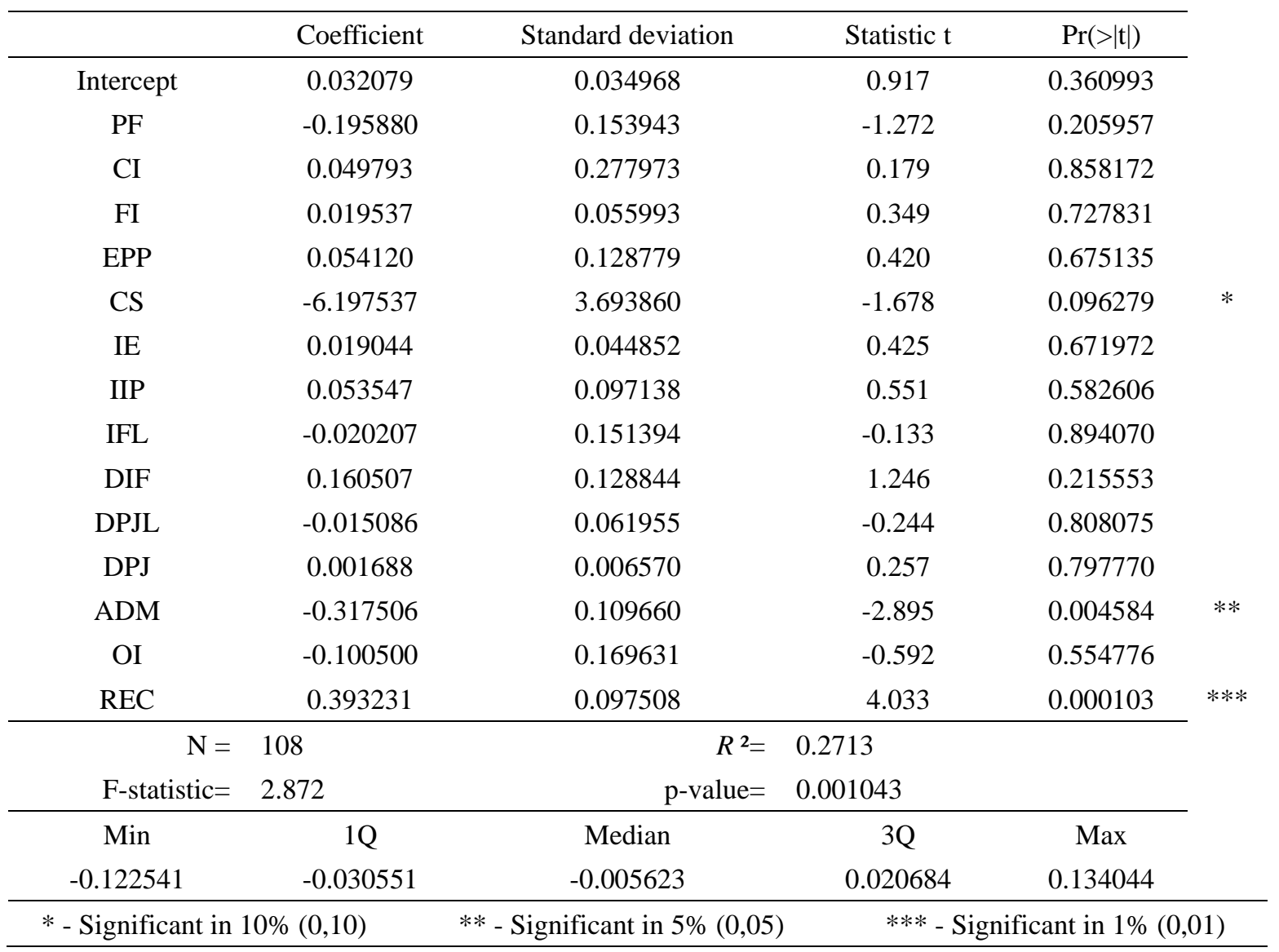

Source: Prepared by the authors (2020).

The Insurance Companies (CS) participated in 17 public offerings, while the partners, managers and other persons related to the company and / or participants of the distribution (ADM) were present in the acquisition of shares in 44 public offerings. In turn the share repurchase procedures within the scope of price stabilization activities (REC) were carried out on 45 share distribution offerings, it was expected that the effect on the abnormal return would be present with this variable, since the procedure only starts if there is a momentary change in liquidity as from the share launching. Thus, we can consider the result indicated by the statistical model as accepted for the independent variables CS, ADM and REC, since the number of participants can be considered satisfactory, in view of the sample size. 
The results reported in Table 7, with the control variables, show that some of the dependent and control variables, used to explain the $\mathrm{H}_{0,2}$, model, have statistical significance ADM, REC, STR and ROA.

Table 7. Study model H0,2 with control variables

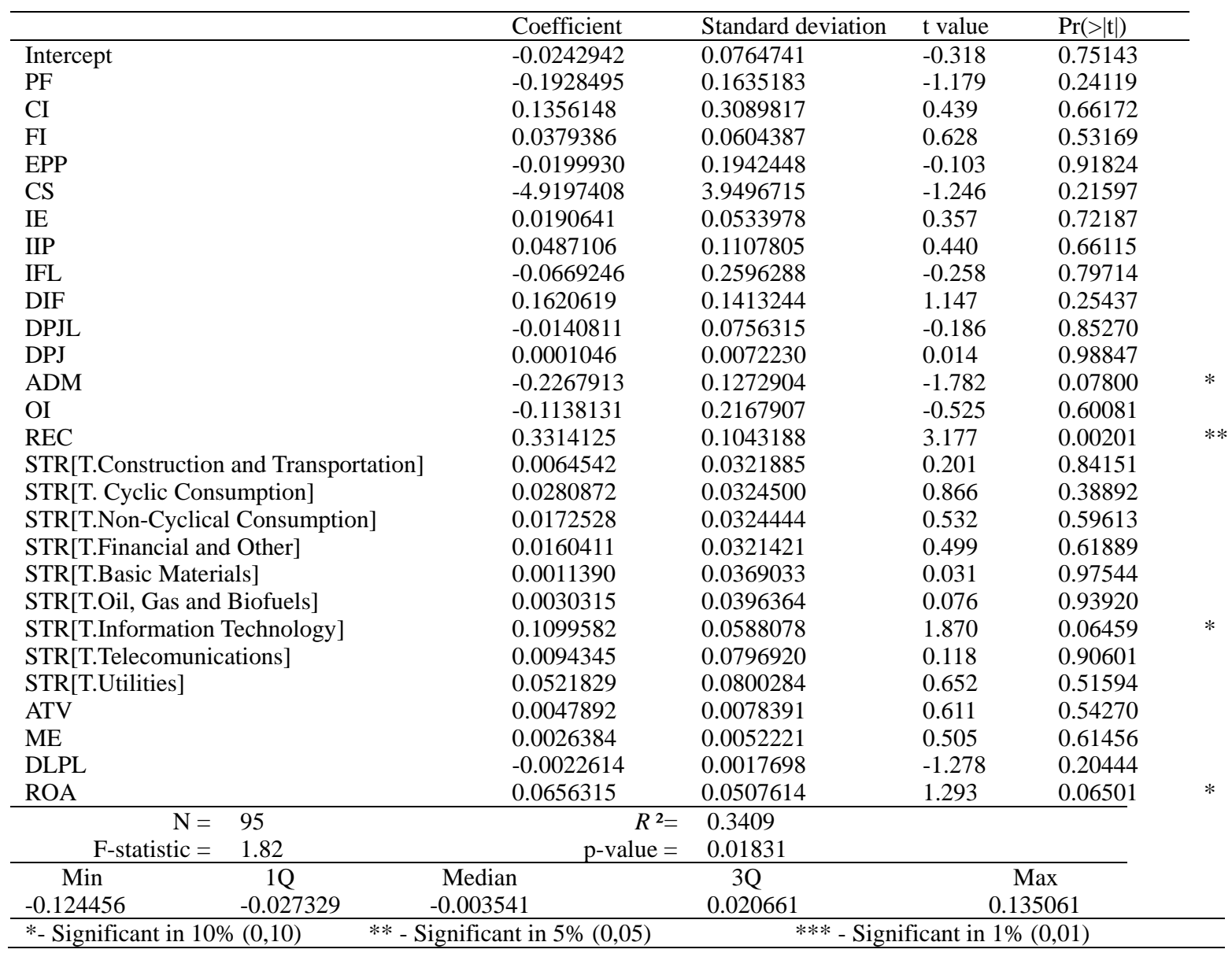

Source: Prepared by the authors (2020).

Such evidence also suggests that the profile of investors participating in an offer does not take effect as a whole in view of the Abnormal Return (RA) of the shares on the first trading day. The $\mathrm{R}^{2}$ was equal to 0.03409 which apparently indicates the relevance of the studied model.

As for the independent variable ADM, which corresponds to the partners, directors and other people connected to the company and / or to the participants of the distribution, the variable presented statistical significance at $10 \%$, that is, the abnormal return tends to be negative when people connected to the company participate in the offer. The independent variable REC once again showed a positive return.

Finally, as pointed out in previous studies, ROA is presented explaining the abnormal returns to the statistical significance level of $10 \%$. Such control variable has met the expected behavior as well as those described by Mcguire et al. (1988), Lopes and Galdi (2007) and Lopes et al. (2010).

\subsection{Concluding Remarks}

This research aimed to study the relationship between the fund's allocation originated from the fundraising in a primary offering of shares and the abnormal return of shares on the first trading day. Also, there was the additional goal of seeking evidence of the investors participating in the offer and its effects on the abnormal return.

To this end, it was proposed to use information on the allocation of funds raised from public offerings for the distribution of shares from January 2007 to December 2011, as well as information on the participants in the offers made available in the statement of closure of deals.

The estimates of the $\mathrm{H}_{0,1}$ model suggest that there is no relationship between changes in stock prices on the first trading 
day at the Stock Exchange session and the allocation of funds raised from the primary offer. So, the null hypothesis was rejected. However, the model worked for the control variables that include financial indicators such as ROA and leverage (net debt over net worth).

We have not found evidence strong enough to explain $\mathrm{H}_{0,2}$, which deals with the moment after the shares launching, through the announcement of the offer closing to the market. In this information, it was expected to see the relationship between the participants in the offer and the abnormal returns, however it was possible to observe only a negative relationship between the return and the participation of the partners, directors and other people connected to the company and / or the participants in the distribution. Regarding the share repurchase procedures under the price stabilization activities it was possible to establish a relationship with the abnormal returns. Once again, the model worked for ROA control variable, consistent information with finance theories.

It is believed that the difficulty in obtaining more conclusive results that could also corroborate the finance theories is due, at least in part, to the poor quality of the information disclosed in the public offering prospectuses regarding the funds allocation. When analyzing the prospectuses, it was possible to observe patterns set by the coordinators of the offerings, that is, considering an investment bank as the coordinator, virtually all prospects under its responsibility followed the same informational pattern. Since, the mandatory presentation of the funds allocation, given by ICVM 400 and its subsequent updates, are made in figures or percentages by companies, it is suggested for the future that this information is improved, with measures such as (i) better explain the concept of funds allocation, (ii) create clearer mechanisms to assess the quality of information provided by the companies, as the form of presentation varied among the prospectuses, (iii) create mechanisms of control subsequent to the offer in order to check the use of funds and their justifications. During the preparation of this research, no literature was found addressing these aspects.

Suggestions to be considered for further study include (i) the expansion of the universe of companies studied, being essential, in this case, to observe the period before and after the implementation of ICVM Instruction 400 of December 29, 2003; and (ii) keep up with the financial reports published by the companies, subsequent to the offer, the identification of the effective use of funds raised, as well as the effect of the shares price variation in the subsequent periods.

\section{Acknowledgements}

This work was made possible through the support of the Institute for Accounting, Actuarial and Financial Research (FIPECAFI), the Institute of Management Foundation (FIA) and the University of São Paulo (USP). The opinions, hypotheses and conclusions or recommendations expressed in this material are the responsibility of the author (s) and do not necessarily reflect the opinion of the institutions.

\section{References}

(1994). Fractal Market analysis: applying chaos theory to investment and economics. New York, NY: John Wiley \& Sons.

Aggarwal, R., Leal, R., \& Hernandez L. (1993). The aftermarket performance of initial public offerings in Latin America. Financial Management, 22, 42-53. https://doi.org/10.2307/3665964

Brau, J. C., \& Fawcett, S. E. (2006). Initial Public Offerings: An Analysis of Theory and Practice. The Journal of Finance, 61(1), 399-436. https://doi.org/10.1111/j.1540-6261.2006.00840.x

Brealey, R. A., \& Myers, S. C. (2008). Finanças Corporativas: Financiamento e Gestão de Risco (1st ed.). São Paulo, SP: Bookman.

Comissão de Valores Mobiliários - CVM (2003). Instrução CVM No 400 - Dispõe sobre as ofertas públicas de distribuição de valores mobiliários, nos mercados primário ou secundário, e revoga a Instrução 13/80 e a Instrução 88/88. Legislação. Rio de Janeiro. Accessed: 2020-05-22. http://www.cvm.gov.br/legislacao/instrucoes/inst400.html

Corbett, J., \& Jenkinson, T. (1997). How is Investment Financed? A Study of Germany, Japan, UK and US. Working Papers 16, American Institute for Contemporary German Studies.

Dalmácio, F. Z. (2009). Mecanismos de governança e acurácia das previsões dos analistas do mercado brasileiro: uma análise sob a perspectiva da teoria de sinalização. Doctoral dissertation, University of São Paulo, São Paulo, Brazil. https://doi.org/10.11606/T.12.2009.tde-17122009-171118

Fama, E. F. (1976). Efficient Capital Markets - Portfolio Decisions and Securities Prices. New York, NY: Basic Books. Iudícibus, S., \& Lopes, A. B. (2004). Teoria Avança da Contabilidade (1st ed.). São Paulo, SP: Atlas.

Kahneman, D. (2003). Maps of bounded rationality: psychology for behavioral economics. American Economic Review, 93(5), 1449-1475. https://doi.org/10.1257/000282803322655392 
Kayo, E. K. (2002). A Estrutura de Capital e o Risco das Empresas Tangível e Intangível-Intensivas: Uma Contribuição ao Estudo da Valoração de Empresas. Doctoral dissertation, University of São Paulo, São Paulo, Brazil. https://doi.org/10.11606/T.12.2002.tde-05032003-194338

Keloharju, M. (1993). The Winner's Curse, Legal Liability, and the Long-Run Price Performance of Initial Public Offerings in Finland. Journal of Financial Economics, 34(2), 251-277. https://doi.org/10.1016/0304-405X(93)90020-C

Korajczyk, R. A.; Lucas, D. J., \& Mcdonald, R. L. (1991). The Effect of Information Releases on the Pricing and Timing of Equity Issues. The Review of Financial Studies, 4(4), 685-708. https://doi.org/10.1093/rfs/4.4.685

Ljungqvist, A.; Boehmer, E. (2001). The Choice of Outside Equity: An Exploratory Analysis of Privately Held Firms. NYU Working Paper No. S-CG-01-01. https://ssrn.com/abstract=1295759

Lopes, A. B., \& Galdi, F. C. (2007). Does financial statement analysis generate abnormal returns under extremely adverse conditions? Annual Meeting of the American Accounting Association, Chicago.

Lopes, A. B., \& Martins, E. (2010). Teoria da Contabilidade: Uma Nova Abordagem (1st ed.). São Paulo, SP: Atlas.

Loughran, T., \& Ritter, J. R. (2002). Why Don't Issuers Get Upset About Leaving Money on the Table in IPOs? The Review of Financial Studies, 15(2), 413-443. https://doi.org/10.1093/rfs/15.2.413

McGuire, J. B., Sundgren, A., \& Schneeweis, T. (1988). Corporate social responsibility and firm financial performance. Academy of Management Journal, 31(4), 854-872. https://doi.org/10.5465/256342

Modigliane, F., \& Miller, M. H. (1958). The cost of capital corporation fiannce, and the theory of investment. America Economic Review, 48(3), 261-297. Received from https://www.jstor.org/stable/1809766

Morris, R. D. S. (1987). Agency theory and accounting policy choice. Accounting and Business Research, 18(69), 47-69. https://doi.org/10.1080/00014788.1987.9729347

Myers, S. C., \& Majluf, N. S. (1984). Corporate financing and investment decisions when firms have information that investors do not have. Journal of Financial Economics, 13, 187-221. https://doi.org/10.1016/0304-405X(84)90023-0

Peters, E. (1991). Chaos and order in the Capital Markets, a new view of cycles, prices and market volatility. New York, NY: John Wiley \& Sons.

Ritter, J. R. (1991). The Long-Run Performance of Initial Public Offerings. The Journal of Finance, 46(1), 3-27. https://doi.org/10.1111/j.1540-6261.1991.tb03743.x

Ritter, J. R., \& Welch, I. (2002). A Review of IPO Activity, Pricing and Allocations. The Journal of Finance, 57(4), 1795-1828. https://doi.org/10.1111/1540-6261.00478

Saito, R., \& Maciel L. P. (2006). Underpricing of Brazilian IPOs: Empirical Evidence from 1999 to 2005. Encontro da Associação Nacional de Pós-Graduação e Pesquisa em Administração - EnANPAD, Anais, XXX, Salvador, Brazil.

Varian, H. R. (2006). Microeconomia. Princípios Básicos. Uma Abordagem Moderna. (7th ed.). Elsevier.

\section{Copyrights}

Copyright for this article is retained by the author(s), with first publication rights granted to the journal.

This is an open-access article distributed under the terms and conditions of the Creative Commons Attribution license which permits unrestricted use, distribution, and reproduction in any medium, provided the original work is properly cited. 